\title{
Environmental Injustice: Exploitation of Sindh's Natural Resources in Pakistan
}

\author{
Abdul Hadi \\ Ph.D Student. Ankara University, Faculty of Letters, Department of Sociology, Sihhiye, 06110, Ankara,Turkey \\ Email address: hadijarwar@gmail.com
}

\section{Doi:10.5901/ajis.2015.v4n1s1p9}

\begin{abstract}
Immediately after the creation of Pakistan, attempts were started to obliterate the proven history of Sindh as its being a separate state and nation, having its own creed, heritage, culture, language and traditions. Sindh is enriched with oil and gas resources but people of Sindh are living in pathetic conditions. The majority of people who resides in natural resource-enriched regions find difficulty to meet their basic needs. The surrounding area of oil and gas fields are polluted, local people bear the burden of this pollution. The aim of this paper is to understand that why natural resource-enriched soil of Sindh's people live in abject poverty and lag far behind in human development indicators. The prevalence of internal colonialism has been noted in this study where a dominant ethnic group Punjabi in control of a government systematically exploits resources of Sindhi people. This is an environmental injustice with Sindhis resulting from their subordinate and peripheral status in Pakistan.
\end{abstract}

Keywords: Environmental Injustice, Internal-colonialism, Oil and gas, Resource exploitation, Sindh

\section{Introduction}

Pakistan is not one country composed of only one Nation but is a conglomeration of socio-cultural different nationalities. The 'ethnic minorities' that basically comprise the smaller nations of Pakistan never supported the creation of Pakistan. Unlike Baluch and Pashtuns, Some Sindhi reluctantly did support the Lahore resolution of March 23, 1940. According to Lahore resolution, the Muslim-majority areas to "be grouped to constitute independent states in which the constituent units shall be autonomous and sovereign". But in the Delhi session of the All India Muslim League held in 1946, the original wordings were changed to "A sovereign state of Pakistan"(Syed, 1989). Seeing the changing attitude and act of betrayal of All India Muslim league, Few Sindhis who supported the Lahore resolution, withdrew their support to any future political set up called Pakistan and stood against the All India Mulsim League. "The election of 1946 were a kind of virtual referendum on the partition, in which the anti-partition Unionist Party won in Punjab; Congress won in NWFP (Now KPK); the all India Muslim league (AIML) lost in Sindh, giving lead to Indian National Congress (INC) and Sindhi nationalist forces. Thus, the idea of Pakistan was rejected by the Sindh, Balochistan and Khyber Pakhtunkhawa provinces. Balochistan was not part of Pakistan in 1947 and Sindh rejected AIML in the 1946 elections, i.e. both aspired to reclaim the status of sovereign countries, which they lost after Britain's 1843 invasion (Shah, 2014). But British imperialists decided to divide up India for strategic reasons and purposely set out to create a new state called Pakistan against the wishes of Sindh and other minority ethnic groups.

Narendra Singh Sarila, a retired Indian diplomat, gives detailed and clear-cut evidence showing that in March, 1945 then British Prime minister Churchill and the British general staff took decision to divide up India for strategic reasons and purposely set out to create a new state called Pakistan. Thus, Pakistan came into existence. The Pakistani state was created by putting together ethnic groups that had never before been united in the same polity before British. Sindhi, Baluch and Pashtuns resisted Punjabi invasions for centuries. After the construction of Pakistan, Sindhi, Baluch, and Pashtuns feel that they are trapped in a political set up which is run by dominant province Punjab since Punjab controls armed forces and key political institutions (Harrison, 2009).

Historically Sindh remain a sovereign country. Since the creation of Pakistan, Sindhi lost their political autonomy which has eventually threatened their distinct culture and language (UNPO, 2012). Despite the fact that, Sindh is enriched with oil and gas resources but its people are poor and live miserable lives. All their resources, Sindhis alleged are used for the development of Punjab; whereas, Sindhis bear the burden of environmental degradation resulting from operation of companies in fields. Thus, Sindhis are facing environmental injustice. 


\section{Research Methodology}

This is a theoretical research, based on secondary data. In order to comprehend the issue in hand, many books and scientific articles were studied. Besides that, official statistics, documents, and local newspapers concerning to the issue were analyzed and evaluated.

\section{Environmental Injustice: Exploitation of Sindh's Natural Resources in Pakistan}

Environmental injustice takes place when some people or communities bear environmental burdens disproportionately, like those of hazardous waste dumps, or has unequal access to environmental good, like clean air, or has less opportunity to participate in environmental decision-making process (Shrader-Frechette, 2002: 3).

Sindhis have been complaining about growing injustices to them since the inception of Pakistan. Be it the distribution of resources, apportionment in budget, water rights, share in economic development, expenditure in social sectors, education, health and infrastructure development, their involvement in the decision making process, they are ignored everywhere (Narejo, 2011 ). The majority of people who resides in natural resource-enriched regions find difficulty to meet their basic needs. The vast majority of Sindhis are jobless, hungry and impoverished. Despite the richness of Sindh in oil and gas, it is lagging far behind in human social indicators. Sindhis live in abject poverty. Since the inception of Pakistan, Sindh has virtually turned into a colony. A series of injustice and miseries of Sindh will be analyzed and evaluated through internal-colonialism perspective.

\section{Internal-colonialism and Sindh}

Colonialism is a process in which more powerful nations exploit other nations and show their economic and sociopolitical dominancy over them. In contrast, internal colonialism is a condition in which both the dominant group and subordinate groups co- exist as natives of the same society (Adeola, 2000).

The prevalence of internal colonialism has been noted in studies of ethnic problems. Internal colonialism results where an ethnic group in control of a government systematically exploits resources of the regions occupied by minority ethnic groups. Typical results include an inequitable distribution of national wealth and of access to employment and educational opportunities. With local resources and income used primarily to serve the interests of the dominant ethnic or religious group, the resemblance to traditional colonialism is strong (Sornarajah, 1981).

Sindh, the second largest province in Pakistan, is richest in the natural resources like gold, gas, oil, coal and uranium. Sindhi scholars and Sindh rights activist claim, according to Sindhi newspapers of Pakistan, that Punjabi being a dominant ethnic group abused its absolute power to usurp and transfer resources from the periphery (Sindh) to develop the core areas (Punjab), while creating immiseration and increased inequality among the subordinated resourcedependent ethnic periphery Sindh.

\section{Oil \& Gas Resources in Sindh}

Catching a glimpse of scruffy towns and villages of Sindh where oil and gas produced, one would not believe that the areas overlay the wealth of hydrocarbons worth several billion dollars.

Pakistan Energy Year Book 2013 shows that Sindh contribute 40.6 percent of oil in the total national oil production. Recent oil discoveries of in KPK dwarfed Sindh's share from 56 percent till only two years back. See the below table for details.

\begin{tabular}{|c|c|c|}
\hline Province & Oil Production (Million Barrels) & \% Share \\
\hline Sindh & 11.37 & 40.63 \\
\hline Punjab & 5.26 & 18.90 \\
\hline KPK & 11.24 & 40.4 \\
\hline Baluchistan & 0.2 & 0.07 \\
\hline Pakistan & 27.84 & 100 \\
\hline \multicolumn{2}{|c|}{ Source: Pakistan Energy Yearbook 2013, Ministry of Petroleum and Natural Resources, Government of Pakistan } \\
\hline
\end{tabular}

Pakistan Energy Year Book 2013 shows that, share of Sindh contribute 68.65 percent of gas in the total national gas production. See the below table for details. 
Table. Province-wise Gas Production: 2012-13

\begin{tabular}{|c|c|c|}
\hline Province & Total (MMCF) Million Cubic Feet & \% Share \\
\hline Sindh & $1,033,794$ & 68.65 \\
\hline Punjab & 69,220 & 4.6 \\
\hline KPK & 126,234 & 8.38 \\
\hline Baluchistan & 276,593 & 18.37 \\
\hline Pakistan & $1,505,841$ & 100 \\
\hline \multicolumn{2}{|c|}{ Source: Pakistan Energy Yearbook 2013, Ministry of Petroleum and Natural Resources, Government of Pakistan } \\
\hline
\end{tabular}

These tables highlight that Sindh is the largest oil and gas producing province of Pakistan and largest contributor in national energy basket.

Table. Province-wise Gas Production and Consumption Trend, 2012-13

\begin{tabular}{|c|c|c|c|}
\hline Province & Total Gas Produced (Million Cubic Feet) & Total Gas Consumed (Million Cubic Feet) & $\begin{array}{c}\text { Ratio (Consumption vs } \\
\text { Production in \%) }\end{array}$ \\
\hline Sindh & $1,033,794$ & 576,519 & 55 \\
\hline Punjab & 69,220 & 542,185 & 783 \\
\hline KPK & 126,234 & 65,179 & 51 \\
\hline Baluchistan & 276,593 & 84,097 & 30 \\
\hline \multicolumn{2}{|l}{ Source: Pakistan Energy Yearbook 2013, Ministry of Petroleum and Natural Resources, Government of Pakistan } \\
\hline
\end{tabular}

The table shows that Sindh consumes only a part of its production and much of its production is utilized in Punjab. Punjab consumes 783 percent against its production in the national output of gas. The highest utilization of gas by Punjab produced by other provinces, indicates that Punjab is the center of much of the development in Pakistan.

The employment of local people is another major issue. Fields of oil and gas are chiefly in far-flung and underdeveloped areas of Sindh. Whereas the head offices of operating companies are located in big cities in oil where Sindhi speaking staff hardly makes a small fraction of their human resource. Sindhi speaking are to some extent, recruited in field staff as low paid unskilled labor owing to non-feasibility of recruiting people from other provinces. It must be kept in mind that Directorate General of Petroleum Concessions (DGPC) of the Federal Ministry of Petroleum and Natural Resources is responsible for overall employment regime of these companies (Memon, 2014).

\section{State of Human Development in the Oil and Gas Producing Sindh}

Sindh is facing injustice with the day when Pakistan came into existence. Its own resources are usurped by the rulers of Pakistan and utilized for the development of dominant province Punjab; whereas Sindhis are facing miseries .50 percent of its population live below the poverty line (Kazmi, 2008).

Sindh produces 40.63 and 68.65 percent of oil and gas respectively. Estimated value of oil produced from Sindh at the rate of US\$100/barrel comes around 113 billion rupees per year. Estimates of gas are difficult to establish as different companies have different rates. However the income from gas is much higher than that of oil. Though Sindh is the largest oil and gas producing province in Pakistan, Its people are living in abject poverty. The larger part of oil and gas producing areas of Sindh lags far behind in (HDI) human development indicators. In the oil and gas producing areas of Sindh, human development indicators are very dismal with most of the people living below poverty line. These areas are mostly under-developed and people surrounding the oil and gas fields live in primitive ages. Some credible research reports corroborates the fact (Memon, 2014).

According to Human Development Report of UNDP (2003) Badin, the major oil producing district ranked at 60th out of 91 districts in the country (Memon, 2014). The Millennium Development Goals Report 2005 issued by the government shows the ranking of three major oil and gas producing districts of Sindh against key development indicators. A New Deal in Pakistan" by Dalrymple (2008) said that Sindh is one of the most under-developed areas in Asia. It lags far behind in all index of development. A leading English newspaper in Pakistan, "Dawn" wrote in its editorial that in spite of Sindh's largest share in the production of oil and gas in Pakistan, people surrounding the oil and gas fields are forced to cut down trees for their survival. In the 16 districts producing oil and gas, the socioeconomic indicators are dismal with most of the people living below the poverty line, without basic health and education facilities or even clean water. Local 
inhabitants complain of neglect, deprivation and injustice (PDI, 2010).

Sindh Provincial assembly in 2008 passed a resolution in which it asked the federal government of Pakistan to implement regulations which can compel gas and oil companies operating in Sindh to invest in social development of areas where oil and gas fields are located. However, Federal government in collusion with the gas and oil companies refused to implement these regulations. It must be noted that federal government has made a set up to ensure that much of gas produced in Sindh can be diverted to Punjab (Hashmani, 2009). Economy of Sindh has been weakened since many years because it is used to meet the development targets of Punjab and fulfill federal and military demands (Rahman, 2009).

Instead of being beneficial for Sindhis, oil and gas have harmed them. Sindhis bear the burden of pollution due to the operation of oil and gas companies. People surrounding the oil and gas fields often make complaints about the pollution caused by the companies operating in these areas. The operation of companies have degraded the environment (Memon, 2009). Thus, they are subjected to environmental injustice due to their subordinate and peripheral status in Pakistan.

\section{Conclusion}

It is crystal clear that Sindhs are deprived of benefits from natural resources being extracted from their own soil.

Despite of the fact that Sindh is enriched with natural resources, its people are deprived of the benefits of the resources extracted from their own soil. Punjab being a dominated province is exploiting all these resources for the development of its own people and province. Whereas, Sindhis have been paying the prices of oil and gas in shape of the degradation of their fertile lands and environment.

People surrounding the oil and gas fields often make complaints about the pollution caused by the companies operating in these areas. They complain that specific chemical used by companies during the extraction of oil and gas process, has contaminated the underground water causing health concerns. Thus, Sindhis are subjected to environmental injustice due to their subordinate and peripheral status in Paksitan.

\section{References}

Adeola, F.O. (2000). Cross-National Environmental Injustice and Human Rights Issues, a Review of Evidence in the Developing World. Dalrymple, W. (2008). A New Deal in Pakistan. The New York Review of Books.

Dawn Editorial. (2009). Dawn Newspaper. Retrieved From. http://www.dawn.com/news/1071958/dawn-editorial-february-02-2009.

Harrison, S.S. (2009). Pakistan: The State of the Union. Special Report. Center for International Policy.

Hashmani, K. (2009). Poor People in Resource Rich Sindh! Indus Asia Online Journal (iaoj).

Kazmi, E. (2008). Ameer Sindh Jo Ghareeb Awam. Published by Sindh United Party.

Memon, N. (2014). Oil \& Gas Resources and Rights of People (Case of Sindh). Center for Peace \& Civil Society.

Memon, N. (2009). Sharing oil and gas resources. Daily Dawn. Retrieved from http://www.dawn.com/news/337328/sharing-oil-and-gasresources

Narejo, A. (2011).Injustices in Pakistan: Startling Disclosures of Federal Employment Figures. Indus Herald.

Pakistan Energy Yearbook. (2013). Ministry of Petroleum and Natural Resources, Government of Pakistan.

PDI. (2010). Poverty in oil-rich districts of Sindh. Participatory Development Initiatives. Retrieved from http://pdipakistan.blogspot.nl/2 010/03/poverty-in-oil-rich-districts-of-sindh.html

Rahman, H. (2009). Ethnic Tensions and the Future of Pakistan: The Case of Sindh. Pakistan: The State of The Union. Special Report. Center for International Policy.

Sarila, N.S. (2009). The Shadow of the Great Game: The Untold Story of India's Partition.

Shah, Z. (2014). Speak out: Sixty Seven Years of Pakistan. Published by Truthout. Retrieved from. http://truth-out.org/speakout/item/ 25582-sixty-seven-years-of-pakistan.

Shrader-Frechette. (2002). Environmental Justice: Creating Equality, reclaiming Democracy. Oxford University Press.

Sornarajah. (1981). Internal Colonialism and Humanitarian Intervention M., Ga., J., Int'l \& Comp., L. [Vol. 11:1.

Syed, G.M. (1989). Sindhudesh: A Study in Its Separate Identity through the Ages. (Translation of "Sindhu Ji Saanjah" in Sindhi).

UNPO. (2012). Report of The General Secretary to the 11th UNPO General Assembly May 2010 - November 2012. UNPO International Secretariat. Unrepresented Nations and Peoples Organization.

UUDP. (2003). Poverty, Growth and Governance. Pakistan National Human Development Report. United Nations Development Programme.

UNDP. (2005). Pakistan MDG Report 2005 